\title{
studia
}

${ }^{2}$ HISTORII HIOLOFHI

1/2010 ISSN 2083-1978

PrZEMYSŁAW WeWIÓR

\section{Nauka polityczna Thomasa Hobbesa jako technologia władzy}

Epikurejczycy głosili, że szczęście łatwo osiągnąć, gdyż wszystko, co do niego prowadzi, zostało dane człowiekowi przez naturę. Thomas Hobbes ripostuje: naturalna kondycja ludzka to „bezustanny strach i niebezpieczeństwo gwałtownej śmierci. I życie człowieka jest samotne, biedne, bez słońca, zwierzęce i krótkie" ${ }^{1}$. Przyroda to pole niekończącej się walki ośrodków mocy, dlatego człowiek żyjący w stanie natury nigdy nie może czuć się na swoim miejscu. Zastany świat jest obcy i zupełnie obojętny na ludzkie potrzeby - nie wygląda na przestrzeń zaprojektowaną jako wygodny dom. Szczęście zatem stoi przed ludźmi jako zadanie: to, czego nam odmawia natura, pozyskujemy poprzez sztukę. Rozum i ręce stanowią narzędzia, z pomocą których homo faber stwarza odpowiadające jego pragnieniom światy. Dopiero przetworzona przyroda jest otoczeniem, w którym człowiek może choćby na chwilę zapomnieć o stanie chwiejnej równowagi ludzkiej natury i poczuć się jak u siebie, na swoim miejscu.

Okres wczesnonowożytny stanowi zaczątek materialnego postępu. O ile nowa epistemologia i teorie naukowe budzą opór zachowawczych, uniwersyteckich społeczności, to dzieła pracy technicznej wprawiają w zachwyt i zdumienie szerokie grona osób. Użyteczność i rozmach wynalazków i kon-

${ }^{1}$ Th. Hobbes, Lewiatan, czyli materia, forma i władza państwa kościelnego i świeckiego, przeł. Cz. Znamierowski, Warszawa 1954, s. 110 [= Lewiatan]. 
strukcji skłaniają pisarzy do spekulacji na temat nieograniczonych możliwości twórczych człowieka. Tak na przykład Marin Mersenne wychwala sztuki, które „przynoszą tak cudowne wyniki, iż wydaje się, że ludzie mogą naśladować najwspanialsze dzieła Boga"2.

Człowiek powołujący do istnienia nowe światy faktycznie przypomina Stworzyciela. Nowa technika, umożliwiając ludziom współudział w boskim akcie kreacji, napawa dumą, która w przypadku Hobbesa przyjmuje gorszący współczesnych teologów wyraz. Twierdząc, że politykę można potraktować jako dział poetyki, przywołuje on biblijny obraz z Księgi Rodzaju.

Sztuka [...] idzie jeszcze dalej, naśladując rozumny i najbardziej doskonały twór natury, człowieka. Sztuka bowiem tworzy tego wielkiego Lewiatana, zwanego państwem (po łacinie civitas), który nie jest niczym innym niż sztucznym człowiekiem, choć większych rozmiarów i większej siły niż człowiek naturalny, którego obronie i opiece ma służyć [...]. Pakty i umowy, z których pomocą zostały początkowo utworzone części tego ciała politycznego, a później złożone razem i związane w jedno, podobne są do tego fiat, czyli uczyńmy człowieka, które to słowa wypowiedział Bóg w akcie stworzenia ${ }^{3}$.

Wyjaśnić genezę skutku to wskazać i opisać jego przyczyny formalne i materialne. Uniwersalna metoda wyjaśnienia obejmuje swoim zakresem również zjawiska polityczne: „Ażeby opisać naturę tego sztucznego człowieka” - pisze Hobbes o społeczności państwowej - „rozważę [...], z jakiej materii on się składa oraz kto jest mistrzem: jednym i drugim jest człowiek"4. Obywatele, tworząc państwo, odnoszą się nawzajem do siebie. Ludzie, powołujący do istnienia polityczną społeczność, są określani jednocześnie jako przyczyna formalna i materialna. Człowiek jako czynnik sprawczy jest rzemieślnikiem: źródło państwowości bierze swój początek w wytwórczej sprawności obywateli-artystów ${ }^{5}$. Technik, powołując do istnienia nowy artefakt, pozostaje w pewnej relacji do tworzywa - przyczyny materialnej. Szczególny przypa-

${ }^{2}$ Cyt. za P. Rossi, Filozofowie i maszyny (1400-1700), przeł. A. Kreisberg, Warszawa 1978, s. 130 [= P. Rossi].

${ }^{3}$ Lewiatan, s. 5-6.

4 Tamże, s. 6.

${ }^{5} \mathrm{~W}$ wersji angielskiej artificer. Por.: Leviathan, http://books.google.pl/books?id=EKhIRe $\mathrm{k} 0 \mathrm{q} 0 \mathrm{YC} \&$ printsec $=$ frontcover $\& \mathrm{dq}=$ oakeshott + leviathan\&source $=\mathrm{gbs}$ similarbooks_s\&ca$\mathrm{d}=1 \# \mathrm{v}=$ onepage\&q\&f=false s. 82 (dostęp: 2010.05.03); P. Manent, Intelektualna historia liberalizmu, przeł. M. Miszalski, Kraków 1994, s. 46, 50. 
dek, gdy materiałem jest ludzka natura, a celem wytwarzania państwo, jest więc częścią ogólniejszego zagadnienia: stosunku sztuki do przyrody.

\section{Sztuka polityczna a ludzka natura}

Nowożytne poglądy na temat relacji technika-natura ukształtowały się na podstawie Automata autorstwa Herona, pseudoarystotelesowej Mechaniki, neoplatońskiego komentarza Proklosa do Elementów Euklidesa i O architekturze Witruwiusza ${ }^{6}$. W tych tekstach zwracano uwagę na dwa kluczowe elementy procesu tworzenia.

Pierwszym $\mathrm{z}$ nich jest moment racjonalnego konstruowania przedmiotu w czystej wyobraźni. Jeden z najbłyskotliwszych techników XVI wieku, Leonardo da Vinci, wyjaśnia ten wymóg na przykładzie malarstwa: „Ci, którzy lubują się w praktyce bez wiedzy, podobni są do żeglarza, co wsiada do łodzi bez steru i busoli i nie ma nigdy pewności, dokąd jedzie. Praktyka musi być zbudowana zawsze na podstawie dobrej teorii, do której perspektywa jest przewodniczką i bramą i bez niej nie zdziałasz nic dobrego w dziedzinie malarstwa" . Sztuka zostaje zatem określona jako nauka teoretyczna. Wyrażając się w ten sposób, nowożytni mechanicy zdradzają inspiracje hellenistyczną myślą. Aleksandryjscy uczeni tworzyli bowiem modele, ażeby z ich pomocą konstruować innowacyjne przedmioty. Nauki matematyczne ukierunkowane były na projekt i stanowily teorie postępowania technicznego: na przykład geometria była technologią rysunku dokonywanego za pomocą cyrkla i przymiaru, a Archimedesowa mechanika - racjonalną podstawą tworzenia maszyn $^{8}$.

Wytwórczy potencjał nauk teoretycznych jest zasługą jej specyficznej metody. Racjonalna procedura wymaga określenia trzech rodzajów norm: aksjomatycznych, dedukcyjnych i reguł odniesienia. Postępowanie naukowe u swojego początku abstrahuje od rzeczywistych przedmiotów i polega na operacjach, którym poddaje się modele pojęciowe zgodnie z przyjętymi normami rozumowania. Nic nie stoi na przeszkodzie, aby zaniechać zasto-

\footnotetext{
${ }^{6}$ Por. A. C. Crombie, Nauka doświadczalna i artysta racjonalny w Europie w początkach ery nowożytnej, [w:] tegoż, Style myśli naukowej w początkach nowożytnej Europy, przeł. P. Salwa, Warszawa 1994, s. 41 [= Nauka doświadczalna].

${ }^{7}$ L. da Vinci, Pisma wybrane, przeł. L. Staff, Warszawa 2002, s. 215. Por. również tamże, s. 37.

${ }^{8}$ Por. L. Russo, Zapomniana rewolucja: grecka myśl naukowa a nauka nowoczesna, przeł. I. Kania, Kraków 2005, s. 202-203, 214 [= Zapomniana rewolucja].
} 
sowania reguł odniesienia i dokonywać racjonalnych operacji, konstruując w wyobraźni nieistniejące w naturze przedmioty, dzięki którym będzie można zmieniać przyrodę?. Techniczne nastawienie aleksandryjskiej nauki widać bardzo wyraźnie w Euklidesowych Elementach. Poszczególne księgi tego pisma zaczynają się od wyliczeń pierwszych zasad; po nich następują tak zwane problematy (zagadnienia), a później twierdzenia. Zagadnienia, które są ćwiczeniami konstrukcji przedmiotu teoretycznego, zawsze poprzedzają zadania wymagające dowodu ${ }^{10}$.

Przewaga nowożytnych techników nad ich średniowiecznymi kolegami po fachu polega właśnie na tych teoretycznych zdolnościach. W tekście O architekturze Witruwiusza, którego propagatorem w okresie nowożytnym był Leon Battista Alberti, czytamy o sztuce projektowania budynków:

Wiedza ta rodzi się z praktyki i teorii. Praktyka jest to przez ustawiczne ćwiczenie zdobyte doświadczenie, które pozwala na wykonanie rękodzieła z jakiegokolwiek materiału, stosownie do założenia. Teoria zaś jest tym czynnikiem, który na podstawie biegłości i znajomości zasad proporcji może wyjaśnić i wytłumaczyć stworzone dzieło. Dlatego architekci, którzy nie posiadając wiedzy, starali się uzyskać zręczność techniczną, nie mogli zdobyć uznania odpowiadającego ich wysiłkom [...]. Natomiast ci, którzy opanowali obie te dziedziny, jako ludzie wyposażeni w pełen rynsztunek, szybciej osiągali swój cel, a zarazem uznanie. Jak bowiem wszędzie, tak przede wszystkim w architekturze istnieją dwa elementy: przedmiot, który jest określany, i jego określenie. Przedmiotem określanym jest rzecz, o której się mówi; tym, co go określa, jest wywód oparty na zasadach naukowych ${ }^{11}$.

Poetyka to już nie tylko zwykłe rzemiosło, lecz również praca intelektualna. Praktyka techników nie ogranicza się więc do powielania szeregu manualnych procedur stosowanych przez poprzedników, a ich wiedza - do znajomości sposobu wykonania poszczególnych przedmiotów. Teoria podnosi sztukę na wyższy poziom: renesansowi artyści potrafią wskazywać racje de-

\footnotetext{
${ }^{9}$ Por. tamże, s. 31-32.

${ }^{10}$ Podajmy przykłady problematów za tekstem Euklidesa: „Na danej linii prostey oznaczoney, wykreślić troykąt równoboczny [...]; Z punktu danego poprowadzić liniią prostą równą linii prostey daney [...]; Maiąc dane dwie linie proste nierówne, $\mathrm{z}$ większey odciąć linią prostą równą mnieyszey”. Euklides, Euklidesa początków geometryi ksiąg ośmioro..., przeł. J. Czech, Wilno 1817, s. 5-7. Por. Zapomniana rewolucja, s. 202-203.

${ }^{11}$ Pollio M. Vitruvius, O architekturze ksiąg dziesięć, przeł. K. Kumaniecki, Warszawa 2004, ks. I, 1, 1-3.
} 
terminujące szczegółowe przepisy, wyprowadzając je z podstawowych zasad ogólnych, a także projektować innowacyjne rozwiązania techniczne ${ }^{12}$.

Kolejnym krokiem poetyki jest manualna praca, która konkretyzuje racjonalny plan. Daniel Barbaro w XVI-wiecznym komentarzu do Witruwiusza pisze: „artysta działa najpierw w umyśle i pojmuje w rozumie, a następnie naznacza zewnętrzną materię wewnętrzną formą" "13. Drugim ważnym aspektem poznawczym procesu twórczego musi być zatem znajomość przyrody. Człowiek nie jest w stanie utworzyć z materii niczego, co nie leżałoby w jej dyspozycji. Dlatego Arystoteles pisał, że „gdyby na przykład dom był wytworem natury, powstałby w taki sam sposób jak dom wybudowany sztucznie [...]", ponieważ kunsztem „sztuka częściowo uzupełnia to, czego natura nie może urzeczywistnić, a częściowo ją naśladuje" ${ }^{14}$. Stagirycie wtóruje nowożytny matematyk, Guidobaldo del Monte: „Sztuka ze wspaniałą zręcznością przewyższa naturę poprzez samą naturę, tak organizując rzeczy, jak uczyniłaby to sama natura, gdyby uznała, że sama powinna osiągnąć takie rezultaty" ${ }^{15}$. Witruwiusz zaś, dociekając początków sztuki, argumentował, że jej genezą jest naśladownictwo natury: „Wzorem dla wszelkich mechanizmów była przyroda [natura machinata - P.W.], która jako nauczyciel i mistrz przez obrót świata nauczyła nas zasad mechaniki" ${ }^{16}$. Poetyka wymaga zatem od artysty wiedzy o naturze: wspólne zainteresowanie uczonych i twórców prawami przyrody doprowadziło w XVII wieku do zespolenia obu dziedzin. O współzależności poznawania i tworzenia pisze Francis Bacon:

Człowiek [...], sługa i tłumacz przyrody, tyle może zrobić i zrozumieć, ile z ładu przyrody czynem lub zmysłem zdoła uchwycić; poza tym nic nie wie i nic więcej nie może. Żadne bowiem siły nie są w stanie rozwiązać albo rozerwać łańcucha przyczyn; i nie można przyrody zwyciężyć inaczej niż przez to, że jej się słucha. Toteż owe dwa bliźniacze cele, mianowicie ludzka wiedza i potęga, to tak naprawdę jedno i to samo, a to, że dzieła nie dochodzą do skutku, wynika najczęściej z nieznajomości przyczyn ${ }^{17}$.

\footnotetext{
${ }^{12}$ Por. P. Rossi, dz. cyt., s. 45-47.

${ }^{13}$ Cyt. Za: Nauka doświadczalna, s. 41.

${ }^{14}$ Arystoteles, Fizyka, przeł. K. Leśniak, ks. II, 199a 22-30.

${ }^{15}$ Cyt. za: Nauka doświadczalna, s. 43.

${ }^{16}$ Pollio M. Vitruvius, $O$ architekturze, ks. X, 1, 4.

${ }^{17}$ F. Bacon, Novum Organum, przeł. J. Wikarjak, Warszawa 1955, s. 41.
} 
Tę samą ideę wypowiada Galileusz, pisząc o inżynierach, którzy zignorowali prawa przyrody i „chcieli zastosować swoje urządzenia do czynności z samej swej natury niemożliwych: a za sprawą zyskanych wyników i oni sami zostali oszukani i inni również byli zawiedzeni w nadziejach, które powzięli na podstawie ich obietnic [...], jak gdyby swoimi maszynami mogli oni oszukać naturę [...] i jej nienaruszalne prawo"18. W istocie wzorem dla uczonego-eksperymentatora był racjonalny artysta - virtuoso, jak nazywał tę postać Alberti ${ }^{19}$. Jeśli uczony wskazał właściwe przyczyny zjawisk, to powinien (przynajmniej potencjalnie) być w stanie wytworzyć badany skutek. Sprawdzian hipotetycznego wyjaśnienia prawa natury odbywa się na drodze praktycznego doświadczenia. Sama procedura eksperymentu nie różni się zasadniczo od metody racjonalnej poetyki: polega na konstruowaniu w wyobraźni teoretycznego modelu, wykonaniu odpowiednich przyrządów i próbie wytworzenia zaplanowanego skutku-zjawiska. Jak sukces technicznego przedsięwzięcia zaświadcza o poprawności rozumowania artysty, tak samo powodzenie eksperymentu jest świadectwem prawidłowego rozpoznania prawa natury przez uczonego. Dlatego XVI- i XVII-wieczni mechanicy często byli zarazem naukowcami i, odwrotnie, badacze natury dostrzegali praktyczne zastosowania swoich odkryć. W istocie różnica między tymi dwoma działaniami polega tylko na spełnianych funkcjach: artysta wytwarza skutek, mając na względzie utylitarne dobro, a eksperymentator - poszerzenie zakresu wiedzy.

Standardy nowoczesnej poetyki dotyczą również sztuki politycznej. Hobbes rozpoczyna swoje traktaty polityczne, przedstawiając opis hipotetycznego modelu nazwanego stanem natury. Zabieg ten pozwala mu abstrahować od nieistotnych czynników, wpływających na zachowanie rozpatrywanych przedmiotów - w tym wypadku obywateli. Niezakłócony ruch ludzi, który zachodzi w idealnych warunkach, jest określany przez definicje: ius naturale (naturalnego uprawnienia) i lex naturalis (normy naturalnej ${ }^{20}$ ). Dedukowa-

${ }^{18}$ Cyt za: Nauka doświadczalna, s. 43.

${ }^{19}$ Por. tamże, s. 28, 44-45.

${ }^{20}$ Zbigniew Stawrowski proponuje tłumaczyć law of nature nie jako prawo naturalne, ale normę naturalną. Będziemy się stosować do tej konwencji, ponieważ pozwoli nam ona jasno ująć różnice zachodzące między prawem natury rozumianym jako naukowy opis procesów zachodzących $\mathrm{w}$ przyrodzie a prawem natury będącym regułą zachowania prowadzącego do ustanowienia politycznej społeczności. Przyjęcie tej propozycji translatorskiej nie stoi też w sprzeczności z duchem tekstów Th. Hobbesa. Filozof z Malmesbury wypowiada się bowiem w pozytywistyczny sposób: prawo jest wyłącznie prawem państwowym; normy naturalne moż- 
ne na podstawie tych pierwszych zasad i kilku pomocniczych pojęć (wojna, przyrodzona równość etc.) konsekwencje wskazują przepisy konstrukcji państwa. Każda przyjęta reguła postępowania musi zostać wyprowadzona z pierwszych definicji - ten wymóg dotyczy nawet powszechnie przyjmowanych reguł znanych z common law i prawa rzymskiego. Dlatego Hobbes postuluje: Stara jest zasada, że chcącemu nie dzieje się bezprawie. „Ale prawdę tego powiedzenia należy wyprowadzić z naszych zasad [naczelnych]"21.

Obywatele-artyści, formułując pierwsze zasady sztuki politycznej, nie powinni tracić z oczu tworzywa, z którego uczynią państwo. Tym materiałem jest wspólna im wszystkim natura ludzka, dlatego „kto ma rządzić całym narodem, ten w sobie samym czytać musi [...] cały rodzaj ludzki"22. Również sztuczna społeczność polityczna powstaje, nie na przekór, lecz poprzez prawa przyrody: zasady konstrukcji należy wywieść z elementarnych i najsilniejszych skłonności człowieka ${ }^{23}$. Sztuka polityczna jest więc zarazem nauką: Hobbes, posiłkując się wiedzą z zakresu fizyki i jatromechaniki (medycyny uprawianej z zastosowaniem kategorii mechaniki i matematyki), metodą syntezy wykazuje, jakie są przyczyny powstania państwa.

Można powiedzieć, że filozofa z Malmesbury zajmował problem technologii władzy, czy też politycznej inżynierii. Zagadnienie bowiem, które próbował rozwiązać, dotyczy racjonalnych reguł zarządzania dużymi zbiorowościami - takich przepisów, które z konieczności muszą prowadzić do zawiązania politycznej wspólnoty. Mówiąc jeszcze inaczej, przedmiot dociekań stanowią zasady determinujące pokojowe współżycie obywateli. Podany schemat postępowania, który jest zarazem przyczyną całkowitą państwa, musi mieć powszechną ważność: rozwiązanie politycznego problemu musi być skuteczne i znaleźć zastosowanie we wszystkich możliwych warunkach. Filozofia polityki nie jest zatem domeną roztropności (sofrosyne), która wskazuje sposoby działania, ważne tylko w poszczególnych wypadkach - tak jak chciałby tego Arystoteles i kontynuatorzy klasycznej filozofii polityki - ani zwyczaju, któ-

na oznaczać wyrażeniem prawo, ale należy pamiętać, że jest to metaforyczne użycie terminu. Jak argumentuje Th. Hobbes, prawem w ścisłym znaczeniu są bezwzględnie obowiązujące nakazy wyrażające wolę osoby uprawnionej do ich wydawania. Por:: Z. Stawrowski, Prawo naturalne a ład polityczny, Kraków-Warszawa 2006, s. 158-159; Lewiatan, s. 141, 236-237, 239-240; Th. Hobbes, O obywatelu, [w:] tegoż, Elementy filozofii, przeł. Cz. Znamierowski, Warszawa 1956, t. 2, s. 257 [= O obywatelu].

${ }^{21}$ O obywatelu, s. 240.

${ }^{22}$ Lewiatan, s. 7.

${ }^{23}$ Por. L. Strauss, Prawo naturalne w świetle historii, przeł. T. Górski, Warszawa 1969, s. 167. 
rego ogólne normy zachowań obowiązują w jakimś ograniczonym zakresie sytuacji, ale rozumu, określającego normy naturalne - podstawę wszelkiego porządku politycznego ${ }^{24}$. Ten wymóg obrazowo wyraził Immanuel Kant: „Problem zorganizowania państwa jest rozwiązywalny, mówiąc bez ogródek, nawet dla narodu diabłów (jeśli tylko posiadają one rozum) [...]"25. Gwarancję skuteczności reguł daje nam wiedza o mechanizmach zachowania człowieka. Pokażmy, jak Hobbes wykorzystuje jatrofizykę do określenia przyczyn powstania wspólnoty politycznej.

\section{Normy naturalne - zasady konstrukcji państwa}

Przyczyny poszczególnych zachowań istot ludzkich są następujące: człowiek, będąc ośrodkiem mocy, dąży do zwiększenia puli dyspozycji sprawczych i unika czynników, które pomniejszają tę sumę lub prowadzą do całkowitej dezintegracji organizmu jako całości. Współoddziaływanie organizmu i czynników środowiskowych, patrząc od strony fenomenalistycznej, przedstawia się podmiotowi w postaci afektów, spostrzeżeń i wyobrażeń. Z prawa natury wypływa naturalne uprawnienie (ius naturale), czyli „wolność, jaką ma każdy człowiek, używania swej własnej mocy wedle swojej własnej woli dla zachowania własnej istoty, to znaczy: swego własnego życia; i co za tym idzie, wolność czynienia wszystkiego, co w swoim własnym sądzie i rozumieniu będzie on uważał za najstosowniejszy środek to tego zachowania" ${ }^{26}$. To, co każdy poszczególny człowiek przeżywa jako przyrodzone uprawnienie, jest z punktu widzenia fizyki koniecznością. Istota czująca nie może działać na własną szkodę ani nawet chcieć postępować w ten sposób ${ }^{27}$.

Korzystając z ius naturale, człowiek stara się dążyć do przyjemności i unikać przykrości. Jest on w stanie realizować to naturalne uprawnienie dzięki

\footnotetext{
${ }^{24}$ Por. tamże, s. $175-178$.

${ }^{25}$ I. Kant, Do wiecznego pokoju: projekt filozoficzny, [w:] tegoż, O porzekadle: To może być słuszne w teorii, ale nic nie jest warte w praktyce; Do wiecznego pokoju: projekt filozoficzny, przeł. M. Żelazny, Toruń 1995, s. 74.

${ }^{26}$ Lewiatan, s. 113.

${ }^{27}$ Dlatego Th. Hobbes uważa, że pakty, w których osoby zobowiązują się do działań na własną niekorzyść, są nieważne i argumentuje, że umowa musi być dorzeczna, a więc też wykonalna. Jako że przedmiotem działania jednostki nie może być nic innego niż jakieś dobro, to zobowiązanie do szkodzenia sobie nie ma mocy wiążącej, gdyż jest niewykonalne. Por. tamże, s. $116,122$.
} 
dwóm dyspozycjom: fizycznej sile i zdolnościom umysłu. Kwanta fizycznych mocy, którymi ludzie są obdarzeni przez naturę, chociaż różnią się wielkością, są jednak dość zbliżone: „Co się tyczy siły cielesnej, to najsłabszy człowiek ma dość siły, ażeby zabić najmocniejszego albo tajemną machinacją albo łącząc się z innymi ludźmi [...]"28. Natomiast władzą umysłu, która pozwala korzystać z ius naturale, jest przyrodzony rozum. Ratio przysługuje wszystkim ludziom (z wyjątkiem dzieci, szaleńców i prymitywnych). Nie znaczy to, iżby była ona dana człowiekowi. Odwrotnie, rozum kształtuje się na bazie zapamiętanych spostrzeżeń i afektów. W istocie rzeczy ratio nie jest niczym innym niż serią aktów rozumowania, to znaczy systematycznych, uporządkowanych wyobrażeń, które są przedstawiane w kolejności albo od skutku do przyczyny (analiza), albo od przyczyny do skutku (synteza). Rozumowanie nie byłoby możliwe, gdyby podmiot nie doznawał (obserwował) skutków działania różnych faktorów. Zapamiętane sekwencje zdarzeń, czyli skojarzone ze sobą obrazy, są podstawą antycypacji. Nawet kiedy dany czynnik przestaje oddziaływać na ciało, to jego conatus wciąż przemieszcza się po ciele, stanowiąc wyobrażenie. Wyobrażenie $\mathrm{w}$ przeciwieństwie do spostrzeżenia można wywoływać z pamięci, również wówczas, gdy rzecz, będąca jego źródłem, jest nieobecna. Podmiot zatem jest w stanie zestawiać ze sobą obrazy i na podstawie skojarzeń sprawdzać albo to, jakie wyobrażenia idą za nimi, albo - jakie idee mogły do nich doprowadzić. Tak uzyskane antycypacje skutków działania rzeczy, jeśli są używane przez podmiot do realizacji ius naturale, Hobbes nazywa doświadczeniem, przezornością, zdrowym rozsądkiem czy po prostu przyrodzonym rozumem.

Jedni lepiej, inni zaś gorzej korzystają z własnej wyobraźni, natomiast różnice w tej zdolności nie mogą być zbyt wielkie, jako że każdy człowiek najmocniej interesuje się własną korzyścią i szczęściem. Filozof z Malmesbury argumentuje: „Co się zaś tyczy władz umysłu [...], to ja widzę jeszcze większą równość między ludźmi, niż co się tyczy siły cielesnej. Albowiem przezorność nie jest niczym innym niż doświadczeniem, które wszyscy ludzie zdobywają $\mathrm{w}$ równej mierze $\mathrm{w}$ jednakowym czasie co do rzeczy, które ich w równej mierze interesują" ${ }^{29}$. Można powiedzieć, że ludzkie istoty wyposażone są w system, który na podstawie wyobrażenia przetwarza dane przychodzące ze środowiska, tak aby posłużyły im jako wskazówki do podejmowania optymalnych działań, prowadzących do maksymalizacji mocy. Hobbes utożsa-

\footnotetext{
28 Tamże, s. 107.

29 Tamże.
} 
mia myślenie z liczeniem, a więc ujmuje człowieka jako zwierzę rachujące. Wszystkie zamierzone działania ludzi poprzedzone są hedonistycznym rachunkiem i (zazwyczaj estetycznym) szacowaniem sił własnych oraz mocy, którymi dysponują ośrodki znajdujące się w ich otoczeniu ${ }^{30}$. Z równości podstawowych uzdolnień wynika, że wszystkim ludziom przysługuje w równej mierze naturalne uprawnienie: „[...] różnica między człowiekiem a człowiekiem nie jest tak znaczna, ażeby na tej podstawie jeden człowiek mógł mieć roszczenie do korzyści, do której inny nie mógłby mieć równego roszczenia"31. Stan natury zostaje przez Hobbesa określony jako sytuacja doskonałej wolności i równości. Wzorując się na Galileuszu, filozof z Malmesbury proponuje czytelnikom, aby przeprowadzili myślowy eksperyment.

Pizańczyk w wyobraźni puszczał swobodnie kule po doskonale gładkich pochylniach, które nie hamowały ich ruchu, natomiast Hobbes powala działać ludziom w stanie natury. W normalnych warunkach każdy działający podmiot, chcąc zrealizować swoje pragnienia, musi liczyć się z realiami: jak naturalny ruch kul jest zniekształcany przez nierówności powierzchni i gęstość powietrza, tak ośrodki władzy i groźni współmieszkańcy są dla jednostki punktami oporu, grożącymi odwetem za naruszenie ich dóbr. Ten zabieg abstrahowania pozwoli nam jednoznacznie i poprawnie odpowiedzieć na pytanie o początki państwowości: czy ludzie, wykorzystujący ius naturale do realizacji żądzy mocy założą wspólnotę polityczną? Wyobraźnia jednoznacznie wyrokuje: to niemożliwe. „Z [...] równości uzdolnień wypływa równość nadziei, że możemy osiągnąć nasze cele" ${ }^{32}$, a dalej - walka o utylitarne dobra i uznanie (żądza sławy) oraz wzajemna nieufność. Te trzy przyczyny sporów prowadzą do nieustającego konfliktu, w którym stroną jest każdy człowiek. Hobbes utożsamia stan natury z sytuacją wojny wszystkich przeciwko wszystkim $^{33}$. Przeprowadzone rozumowanie wskazuje, że nie można wyprowadzić nauki i sztuki politycznej z żądzy mocy: swobodne korzystanie z ius naturale skutkuje anarchią i bezprawiem, prowadzi nas na antypody wspólnoty politycznej.

Ludzie mogą uciec przed nędzą stanu natury, jeśli zastosują się do norm naturalnych. Hobbes określa normy naturalne jako zdrowy rozsądek ${ }^{34}$. Mó-

\footnotetext{
${ }^{30}$ Por. Th. Hobbes, The elements of law: natural and politic, [w]: R. Tokarczyk, Hobbes, Warszawa 1987, s. 256-257.

${ }^{31}$ Lewiatan, s. 107.

32 Tamże, s. 108.

${ }^{33}$ Por. O obywatelu, s. 272.

${ }^{34}$ Por. tamże, s. 212.
} 
wiąc dokładniej, są one konkluzjami przyrodzonego rozumu, wyprowadzonymi z modelowego określenia stanu natury, które dają wskazania, jak należy postępować, żeby uniknąć wojny i jej niebezpieczeństw oraz założyć wspólnotę polityczną, w której wszyscy obywatele będą mogli współżyć ze sobą w pokoju ${ }^{35}$. Hobbes połączył ze sobą dwie tradycje rozumienia $z$ drowego rozsądku: pojęciem tym oznacza nie tylko good reason (poprawne rozumowanie), ale również tak zwany common sense (zmysł wspólnotowy, wspólny), czyli władzę umysłu, która określa powszechnie ważne reguły prowadzące do konsensusu ${ }^{36}$.

Pierwsza norma przyrodzonego rozumu głosi, że „każdy człowiek winien dążyć do pokoju, jak dalece tylko ma nadzieję go osiągnąć, a gdy go osiągnąć nie może, wolno mu szukać wszelkich środków i rzeczy dlań korzystnych w wojnie i ich używać" ${ }^{37}$. Skoro ius naturale nie prowadzi do pokoju, lecz nieuchronnie do wojny, to stąd i z pierwszej normy naturalnej wynika, że „człowiek winien być gotów, jeśli inni są również gotowi, zrezygnować $\mathrm{z}$ tego uprawnienia do wszelkich rzeczy, jak dalece będzie to uważał za konieczne dla pokoju i dla obrony własnej; i winien zadowolić się taką miarą wolności w stosunku do innych ludzi, jaką gotów jest przyznać innym ludziom w stosunku do samego siebie" ${ }^{\prime 3}$, co stanowi drugą normę naturalną. Czy jednak wyrzeczenie się ius naturale nie stoi w sprzeczności z naturą człowieka - jej elementarną inklinacją, która nakazuje dążyć w każdej sytuacji do maksymalnej korzyści? Hobbes twierdzi, że wiążące zobowiązania muszą być dorzeczne, a więc wykonalne. Ludzka natura sprawia, że „przedmiotem każdego aktu woli u każdego człowieka jest jakieś dobro własne. Toteż są pewne uprawnienia, o których nie można sobie pomyśleć, iżby jakiś człowiek zrzekł się ich lub je przekazał jakimikolwiek słowami czy znakami” ${ }^{39}$. Polityczny inżynier, który kazałby działać obywatelom na przekór ich przyrodzonemu dążeniu do własnej korzyści, nie stworzyłby politycznej wspólnoty. Rozum nie jest motorem, zatem nie chcąc ignorować cech ludzkiego materiału, którym staramy się zarządzać, należy spytać o motywację skłaniającą ludzi do wyrzeczenia się uprawnienia do nieograniczonej realizacji żądzy mocy.

\footnotetext{
${ }^{35}$ Por.: tamże, ss. 203-204, 219; Lewiatan, s. 112.

${ }^{36} \mathrm{Na}$ temat dwóch znaczeń $z$ drowego rozsądku por. S. Zabieglik, Krzywe zwierciadło filozofii, czyli dzieje pojęcia zdrowego rozsądku, Warszawa 1987.

${ }^{37}$ Lewiatan, s. 114.

38 Tamże.

${ }^{39}$ Tamże, s. 116.
} 
Ciężar rozważań należy przenieść z problematyki dobra na zagadnienie zła. Na mocy tego samego prawa, które nakazuje każdemu ośrodkowi mocy dążyć do uzyskania optymalnego w danych warunkach kwantum sił, człowiek nie tylko szuka przyjemnych doznań, ale również unika przykrości. Dlatego

„łatwo osądzić, jak mało dogodną dla zachowania i rodzaju ludzkiego, i każdego poszczególnego człowieka jest wojna nieustanna [...]. Kto by więc uważał, iż należy pozostać w tym stanie, w którym wolno wszystko, ten popadłby w sprzeczność z samym sobą. Każdy bowiem z naturalnej konieczności pragnie dla siebie dobra; i nie ma takiego człowieka, który by ową wojnę wszystkich przeciwko wszystkim [...] uważał za dobro dla siebie"40.

Wynik hedonicznego rachunku wypada niekorzystnie: trwanie $\mathrm{w}$ stanie wojny, jako że grozi cierpieniem i utratą życia, czyli rozpadem ośrodka mocy, po prostu się nie opłaca. Przedstawiony zaś w wyobraźni widok cierpień chwyta za serce, wywołując afekt strachu. Emocja ta nie jest spowodowana teraźniejszym wrażeniem zmysłowym, lecz przedstawieniem danym w temporalnym modus odnoszącym się do czasu przyszłego - strach nie jest więc zwykłą awersją. Hobbes precyzuje, że przez wyrażenie strach rozumie obawę, to znaczy przewidywanie $z^{4}{ }^{41}$. Zdolność do antycypacji zła wynika z umiejętności wyobrażenia sobie własnych mocy i dyspozycji czynników, które znajdują się (lub mogą się znaleźć) w naszym otoczeniu. Archimedesowy punkt oparcia zostaje zatem odnaleziony w sferze popędliwej, to znaczy w sferze uczuć przyjemności i przykrości odnoszących się do wyobrażeń ${ }^{42}$. Wyobraźnia jest dźwignią, z pomocą której konstruktorzy państwa potrafią wzbudzić w obywatelach antycypację przyszłych nieszczęść i nieodzownie towarzyszący jej strach, który, będąc emocją, stanowi motor zachowań człowieka, i tym samym podnieść standard ich życia na wyższy poziom - pokojowej wspólnoty, zapewniającej bezpieczne i wygodne życie. Tym samym Hobbes wyprowadza naukę polityczną z drugiej najsilniejszej ludzkiej skłonności strachu, prawa samozachowania ${ }^{43}$ : „[...] gdyby nie obawa, to ludzie z przy-

${ }^{40}$ O obywatelu, s. 215.

${ }^{41}$ Tamże, s. 208p.

42 Dlaczego zdaniem Th. Hobbesa wyobrażenia, dobra ideowe, mogą motywować ludzi silniej niż aktualne uczucia wywoływane przez doznawane przedmioty, wykazywałem szczegółowo w innym artykule. Por. P. Wewiór, Thomasa Hobbesa dedukcja naturalnej kondycji człowieka, „Dialogi Polityczne” 12/2010, s. 13-28.

${ }^{43}$ Por. L. Strauss, Prawo naturalne, s. 167. 
rodzenia swego bardziej by dążyli do władzy niż do zrzeszenia się. Trzeba więc stwierdzić, że źródłem licznych i trwałych społeczności nie jest i nie była wzajemna ludzi życzliwość, ale że była nim obawa wzajemna"44.

Jeśli obywatele chcą żyć w politycznej społeczności, muszą konsekwentnie przestrzegać drugiej normy naturalnej - odstępstwo od niej powoduje powrót do stanu natury. Stąd kolejne wskazanie przyrodzonego rozumu brzmi: pacta sunt servanda ${ }^{45}$. Tę zasadę Hobbes utożsamia ze sprawiedliwością ${ }^{46}$. Chociaż zasada dotrzymywania przyrzeczeń, to jest sprawiedliwego postępowania, stanowi konstytutywny warunek istnienia wspólnoty politycznej, to jednak nie obowiązuje w stanie natury. Na mocy pierwszej normy naturalnej żaden człowiek nie może być zmuszony działać na własną szkodę - na takie zaś niebezpieczeństwo narażeni są ludzie, którzy wyrzekliby się ius naturale, nie mając żadnej gwarancji (poza słowami), że ich współobywatele nie sięgną w dogodnym momencie po swoje naturalne uprawnienie. Hobbes wyjaśnia: „W stanie pierwotnym natury [...] ten, kto pierwszy dopełnia swego świadczenia, oddaje się w ręce swego wroga, co jest sprzeczne z uprawnieniem (którego nigdy zrzec się nie może) do obrony własnego życia i środków do życia" ${ }^{37}$. Strach skłaniający ludzi do porzucenia stanu natury jest zarazem przeszkodą na drodze do realizacji tego celu - wzajemna nieufność nakazuje szykować się do wojny. Ważność norm naturalnych (w tym reguły sprawiedliwości) nie jest bezwzględna, lecz warunkowa. W stanie natury wskazania przyrodzonego rozumu nie obowiązują w ścisłym sensie. Przepisy zdrowego rozsądku utrzymują swój normatywny charakter, ale tylko w sumieniu człowieka, czy też, jak określa to Hobbes, na „forum wewnętrznym”. Obywatel jest natomiast zobligowany do postępowania zgodnie z zasadą sprawiedliwości, gdy ma gwarancję, że nie narazi się tym samym na niebezpieczeństwo ${ }^{48}$.

\footnotetext{
${ }^{44}$ O obywatelu, s. 208. Por. również Lewiatan, s. 175.

${ }^{45}$ Por.: Lewiatan, s. 126; O obywatelu, s. 234-235

${ }^{46}$ Th. Hobbes za Arystotelesem przyjmuje, że sprawiedliwość jest równością: „Niepodobna zaprzeczyć, że sprawiedliwość jest pewnego rodzaju równością; ta równość mianowicie polega na tym, że wobec tego, iż z natury wszyscy jesteśmy równi, jeden człowiek nie powinien przywłaszczać sobie więcej prawa, niż go uznaje dla innego, chyba że ten przydział prawa zdobył sobie na podstawie paktów". O obywatelu, s. 240. Nie będziemy rozpatrywać w tym tekście kolejnych norm naturalnych. Dodajmy tylko, że służą one kształtowaniu sprawiedliwego usposobienia i rozwiązywaniu spornych sytuacji.

${ }^{47}$ Lewiatan, s. 120.

${ }^{48}$ Por.: tamże, s. 139; O obywatelu, s. 252-253. Szczegółowo zagadnienie to jest omawiane również w: Z. Stawrowski, Prawo naturalne, s. 162-179.
} 
Można skłonić ludzi, ażeby dla własnej korzyści nie odstępowali od przyrzeczonych umów, odwołując się, oczywiście, do afektu strachu. Nie chcąc jednak siać między obywatelami wzajemnej nieufności, źródło przemocy należy ulokować w osobie suwerena. Założycielskim paktem politycznego zrzeszenia musi być przeniesienie ius naturale wszystkich twórców państwa na jedną osobę, która na mocy tej umowy uzyskuje władzę najwyższą i absolutną. Jako że uprawnienie do realizacji celu (w tym wypadku władzy) jest realne, o ile obejmuje ono również wolność dysponowania środkami do niego prowadzącymi (odwrotna sytuacja byłaby niedorzeczna), to suweren ma prawo do woli korzystać z mocy, które mają jego poddani ${ }^{49}$. Władza absolutna oddana $\mathrm{w}$ ręce zwierzchnika zapewnia obywatelom przestrzegającym norm naturalnych i starającym się wypełnić zobowiązania wynikające z zawartych paktów gwarancję, że nie zostaną oni zdradzeni przez swoich towarzyszy. Suweren bowiem na mocy założycielskiej umowy, która daje mu uprawnienie do korzystania $\mathrm{z}$ sił obywateli, dysponuje mieczem sprawiedliwości, czyli mocą egzekwowania kar. Tylko perspektywa nieuchronnej i dotkliwej sankcji za popełnione wykroczenia daje gwarancję, że obywatele będą przestrzegać zobowiązań, które zostały na nich nałożone w wyniku umów ${ }^{50}$. Kary zabezpieczają regułę sprawiedliwości, nie tylko działając na ciała przestępców, ale również odwołując się do wyobraźni obywateli, którzy zamierzają popełnić wykroczenia - spełniają one prewencyjną funkcję. Skoro przedstawienie mocy suwerena jest ideą sumy sił wszystkich obywateli, to znaczy, że stanowi też wyobrażenie sumy zła, jakie może dosięgnąć poszczególnego człowieka ze strony swoich współtowarzyszy. Estetyczne szacowanie mocy i hedonistyczny rachunek wypadają na niekorzyść każdego ośrodka mocy, który chciałby popełnić niesprawiedliwy czyn. Suweren, posiadając siłę, ponad którą nie można pomyśleć niczego większego, dysponuje mechanizmem, przy użyciu którego zmienia ruch postępowania obywateli: „Przez to bowiem upoważnienie, jakie mu daje każdy poszczególny człowiek w państwie, rozporządza on tak wielką mocą i siłą mu przekazaną, że strachem przed tą mocą może kształtować wolę wszystkich tych ludzi i zwracać ją w kierunku pokoju wewnętrznego oraz wzajemnej pomocy przeciw wrogom zewnętrznym" ${ }^{51}$.

\footnotetext{
${ }^{49}$ Por. Lewiatan, s. 121; O obywatelu, s. 277.

${ }^{50}$ Por. O obywatelu, s. 285.

${ }^{51}$ Lewiatan, s. 151.
} 


\section{Ciało polityczne w kategoriach Hobbesowkiej fizyki}

Wielość ludzi mocodawców, którzy poprzez pakty uczynili jakąś osobę (suwerena) rozkazodawcą i powierzyli jej środki niezbędne do zapewnienia bezpieczeństwa i pokoju, Hobbes nazywa państwem ${ }^{52}$. Jak każdy wytwór sztuki, tak też i wspólnota polityczna powstaje dzięki rozumnemu zamysłowi i fizycznej sile. Ustanowione artefakty stają się częścią natury w tym samym stopniu, co ciała, których istnienie nie zależy od ludzkiej innowacyjności. Nie inaczej jest z państwem: rządzą nimi prawa natury, które łatwo nam zrozumieć, jeśli potrafimy wskazać dobrze nam znany, analogiczny model. Po ten heurystyczny zabieg sięgali nowożytni uczeni: gdy chcieli wyjaśnić funkcjonowanie złożonego przedmiotu, szukali reprezentującego go prostego i przejrzystego obiektu. Dużo wcześniej tę metodę zastosował Platon, który w Politei opisywał władze ludzkiego ciała i duszy za pomocą zjawisk politycznych ${ }^{53}$.

Podobnie Hobbes przedstawia państwo jako wielkich rozmiarów i przemożnej siły osobę - megalos antropos ${ }^{54}$. Filozof z Malmesbury używa jednak Platońskiej metafory w innym celu: znane jest ciało, nieznane zaś, wymagające wyjaśnienia, to wspólnota polityczna.

W tym sztucznym człowieku - pisze Hobbes o państwie - władza suwerena jest sztuczną duszą, jako że daje życie i ruch całemu ciału; sędziowie i inni urzędnicy wymiaru sprawiedliwości i egzekutywy [...] to nerwy, które czynią to samo, co w ciele naturalnym; bogactwo i dobrobyt wszystkich jego poszczególnych członków jest jego siłą; solus populi (bezpieczeństwo narodu) jest jego zadaniem; doradcy, którzy poddają myśl o wszystkich rzeczach, które państwo znać winno, są jego pamięcią; słuszność i prawo są sztucznym jego rozumem i wolą; zgoda zdrowiem; bunt chorobą; wojna domowa śmiercią ${ }^{55}$.

Skoro ciału człowieka odpowiada automat, to i państwo jest pośrednio reprezentowane również przez maszynę. Idąc tym tropem, można powiedzieć, że suweren jest sprężyną, wprawiającą zrzeszenie polityczne w ruch, władza sądownicza zaś i wykonawcza to nici i koła, które służą prawodawcy

\footnotetext{
${ }^{52}$ Por. tamże, s. $151-152$.

${ }^{53}$ Por. Platon, Państwo, przeł. W. Witwicki, Kęty 2003, 368C-369A.

${ }^{54}$ Por. R. Burger, Śmiertelny bóg: rozważania na temat Lewiatana i pewnej ilustracji, „Przegląd Polityczny" 79/80, 2006, s. 56.

${ }^{55}$ Lewiatan, s. 5-6.
} 
do kierowania obywatelami ${ }^{56}$. Państwo nie jest więc jakimś swoistym układem - jego funkcjonowanie można wytłumaczyć w ramach bardziej ogólnego, jatrofizycznego schematu, który obejmuje wszystkie ciała, wewnętrznie zorganizowane wokół jakiegoś centrum - sterującego ośrodka.

O zrzeszeniu politycznym Hobbes pisze jako o realnej jedności, zjednoczeniu się obywateli w jedną osobę $e^{57}$. Cóż może to znaczyć, jeśli żaden członek państwa nie może podejmować decyzji za nikogo innego, tylko za siebie, i myśleć inaczej niż na własny rachunek? Jako że założycielskiej umowy dokonują wszyscy zainteresowani ludzie, można uznać przeniesienie uprawnień na osobę zwierzchnika za wyraz woli powszechnej ${ }^{58}$. Wszystkie natomiast decyzje suwerena (akty prawne) stanowią wolę całego zrzeszenia politycznego, ponieważ poddani zrzekli się na jego korzyść z ius naturale, przekazując mu tym samym władzę absolutną, której dla zachowania pokoju może używać według własnego, niezależnego osądu. Zatem ustawodawcza wola zwierzchniej władzy nie musi zgadzać się z opinią obywateli. Odwrotnie, to poddany powinien traktować prawne nakazy tak, jakby wyrażały jego prywatną wolę i wykazywać się wobec nich posłuszeństwem: skoro obywatel przekazał swoje naturalne uprawnienie suwerenowi, to na mocy normy naturalnej pacta sunt servanda zobowiązany jest przestrzegać prawa państwowego. Hobbes postuluje: „trzeba, by [...] każdy uznawał i przyznawał, że jest mocodawcą wszystkiego tego, co uczyni lub sprawi, iż zostanie uczynione $\mathrm{w}$ rzeczach dotyczących wspólnego pokoju i bezpieczeństwa, ten, kto reprezentuje ich osobę" 59 . Modelowe i faktyczne postawy obywateli wobec prawa mogą się oczywiście różnić - posłuszeństwo i jedność wspólnoty politycznej zostają wówczas zachowane dzięki przemożnej sile miecza sprawiedliwości, która wymusza na nielojalnych obywatelach postępowanie zgodne z nakazami suwerena.

Wraz z ustanowieniem państwa pośród członków zrzeszenia politycznego zostaje wyróżniona suwerenna osoba (może nią być także demokratyczne lub arystokratyczne zgromadzenie) i jej poddani. Relacje panowania i podległości są precyzowane za pomocą prawa państwowego, które Hobbes porównuje do ograniczających swobodę łańcuchów: „ludzie, by osiągnąć pokój, [...] stworzyli sztuczne łańcuchy, zwane prawami państwowymi, które oni sami,

\footnotetext{
${ }^{56}$ Por. tamże, s. 5.

${ }^{57}$ Por.: tamże, s. 151; O obywatelu, s. 276-278.

${ }^{58}$ Por. O obywatelu, s. 309-313.

${ }^{59}$ Lewiatan, s. 151. Na temat koncepcji suwerenności i indywidualizmu por. P. Mannent, Intelektualna historia liberalizmu, s. 46-51.
} 
mocą wzajemnych ugód, jednym końcem przywiązali do ust tego człowieka czy tego zgromadzenia, któremu dali moc suwerenną, drugim zaś końcem do własnych uszu"60. Tak określone zależności między władzą i poddanymi odpowiadają stosunkom organów centralnych i peryferyjnych żywych organizmów, czy też, ujmując problem jeszcze szerzej, strukturze części automatów. Hobbes porównuje suwerena do duszy, serca i sprężyny, ponieważ władza najwyższa jest źródłem woli (to jest pożądania oraz wstrętu) i siły, która wprawia w ruch służących mu obywateli. Podwładni (członki), doradcy (głowa - wyobraźnia, rozum), policja i sędziowie (nerwy, mięśnie, stawy, nici i koła) nie mogą decydować o losach całości państwa (mówiąc inaczej: nie stanowią motoru politycznej maszynerii), gdyż brakuje im uprawnienia do sprawowania władzy i niezbędnego quantum mocy - władzy absolutnej uzyskanej poprzez powszechną umowę - który pozwala poruszać niczym za pomocą łańcucha każdą częścią cywilnego zrzeszenia ${ }^{61}$.

Państwo jako całość jest ośrodkiem mocy. Napięcie politycznej wspólnoty wytwarza się pomiędzy władzą najwyższą a poddanymi. Ruch koncentryczny wywołuje suweren, jednocząc przemocą obywateli i zapobiegając entropii zrzeszenia, której przyczyną jest nadmierny zakres wolności i dążenie do prywatnych korzyści kosztem sprawiedliwości. Władza jest jednakże dialektyczna: suweren jest panem wobec poddanych, lecz nie wobec wrogów. Dlatego Hobbes pisze, że państwo ma wobec obywateli również obowiązki, które można streścić frazą: należy dbać o dobro ludu ${ }^{62}$. Filozof z Malmesbury wyjaśnia, skąd biorą się zadania stające przed władzą: „Obowiązki suwerena

\footnotetext{
${ }^{60}$ Lewiatan, s. 187.

${ }^{61}$ Th. Hobbes uważa metaforę głowy państwa za nietrafioną: skoro suweren wprawia ciało polityczne w ruch, jest jego wolą, to odpowiada on raczej sercu, czy też duszy jako źródłu motywującego do działania uczucia, a nie impotentnemu rozumowi. Por. tamże, s. 292, 296-297. ${ }^{62}$ W ścisłym sensie suweren nie jest do niczego zobowiązany, gdyż na mocy zawartych paktów nie istnieje żadna instancja, która miałaby uprawnienie do wydawania rozkazów zwierzchnikowi i moc do ich egzekwowania. Powinności władcy wyznaczają normy naturalne - należy dążyć do pokoju. Suweren zwracający się przeciwko obywatelom, czyli dążący do wojny, postąpiłby przeciw nakazom sumienia. Za łamanie przykazań sumienia, jak pokazywaliśmy, nie pociąga się jednak nikogo do odpowiedzialności. O zobowiązaniu władcy w ścisłym znaczeniu tych słów, można mówić, jeśli uzna się Boga za prawodawcę norm naturalnych. Wówczas suweren odpowiada za swoje czyny przed Bogiem, ale nigdy przed ludem. Th. Hobbes pisze jednak o obowiązkach zwierzchnika względem obywateli, bacząc właśnie na normy naturalne. Władca, który umyślnie szkodziłby swoim poddanym, postępowałby niedorzecznie - ryzykowałby utratą uprzywilejowanej pozycji pana, żeby wrócić do niekorzystnej sytuacji wojny. Por. O obywatelu, s. 381-382, 403; Lewiatan, s. 297, 308-309, 317.
} 
[...] wyznacza cel, dla którego została mu powierzona moc suwerena, a mianowicie staranie o bezpieczeństwo ludu, do czego zobowiązuje suwerena prawo natury" ${ }^{\prime 3}$. Nauka, czy też sztuka polityczna jest statyką w makroskali: zwierzchnik musi reprodukować stosunki władzy, chroniąc przed wrogami zewnętrznymi i przestępcami zarówno swoją pozycję, jak i życie obywateli. Dbanie o dobro ludu nie kończy się jednak na zagwarantowaniu socjalnego minimum:

Ludzie samorzutnie zeszli się w państwach stanowionych, iżby mogli, o ile na to pozwala natura ludzka, żyć jak najprzyjemniej. Czyniliby więc niezgodnie z prawem natury ci, którzy przyjęli na siebie sprawowanie władzy [...], gdyby nie dokładali starań, o ile to przy pomocy [sic!] praw jest możliwe, iżby obywatele byli obficie zaopatrzeni we wszelkie dobra potrzebne nie tylko do podtrzymania życia, lecz również dające zadowolenie $\mathrm{z}$ niego ${ }^{64}$.

Suweren interesuje się bogactwem i szczęściem obywateli również dlatego, że siła państwa, będąc sumą mocy obywateli, wrasta wraz z dobrobytem poddanych $^{65}$. Jako że każdy człowiek wie najlepiej, co przyniesie mu szczęście, przeto ludzie powinni dysponować tak szerokim zakresem wolności, jaki tylko nie zagraża publicznemu bezpieczeństwu. Czyny obywateli są ruchem ekscentrycznym politycznego ciała. Antagonizujące moce suwerena i poddanych, jeśli pozostają w równowadze, tworzą pewną wielkość mocy tego zrzeszenia: „Woda objęta zewsząd brzegami zatęcha i się psuje, gdy zaś ze wszystkich stron otworzy się jej ujście, to się rozlewa [...]. Podobnie obywatele, gdyby nie czynili nic bez nakazu praw, to popadliby w stan bezruchu i odrętwienia; gdyby zaś prawa dozwalałyby czynić im wszystko, to by się rozpierzchli [...]"66. Ugruntowana władza i powszechny dobrobyt powiększają quantum sił państwowej osoby, która, bazując na lojalności i bogactwie obywateli, może skutecznie dawać opór czynnikom, które dezintegrują jej strukturę. Wraz z ustanowieniem politycznych zrzeszeń walka ośrodków mocy na śmierć i życie zaczyna toczyć się w wyższym rzędzie wielkości. Zwycięsko z pojedynków wychodzą władcy, którzy, opierając się na znajomości ludzkiej natury, potrafią skłonić poddanych do posłuszeństwa oraz pomnożyć ich siły i bogactwo.

\footnotetext{
${ }^{63}$ Lewiatan, s. 297.

${ }^{64}$ O obywatelu, s. 383.

${ }^{65}$ Por. Lewiatan, s. 5.

${ }^{66}$ O obywatelu, s. 394-395.
} 


\section{Abstract \\ Thomas Hobbes's new political science as a technology of power}

The aim of the article is to demonstrate that Thomas Hobbes created a new model of political science - technology of power or political engineering - and to describe its characteristic. Hobbes's political thoughts was inspired after achievement and methods of alexandrian scientist and technician - for example Heron, Vitruvius, pseudo-Aristotle, Proclos - and theirs renaissance heritors, so-called virtuoso, as Leonardo da Vinci, Leon Battista Alberti and others. The article shows that Hobbes solved question "how to provide a stabile and fair social community or political body?" in the same way as technicians think out problem of forming new artifacts, because conception of law of nature wasn't only an explanation of human conduct, but, on the other hand, a principle of rational construction of state. At the end of paper I show that established political bodies function just like others natural bodies and automats so Hobbes treated on social community using notions of jatrophysics. 